\title{
The aspectual distribution and modal licensing in Russian infinitival constructions
}

\author{
Anna Melnikova*
}

\begin{abstract}
The puzzle to be explored here is why Russian Modal Dative Infinitival Constructions (DMCs) are restricted in their aspectual choice. Specifically, in declarative environments, only imperfective is grammatical. Perfective requires nonveridical environments. This paper offers a unified account for the aspectual distribution in DMCs in terms of licensing conditions on a covert future modal. Extending Todorović and Wurmbrand's (2016) analysis of future infinitives to Russian DMCs, I propose that the difference between perfective and imperfective structures is attributed to the absence/presence of the present tense. The main claim is that similar to English and BCS future tense constructions, DMCs involve a covert future modal (e.g, NEED), which needs to be licensed by non-veridical operators when the infinitival DMC lacks the tense components. The licensing conditions on covert future modals lay the foundation to understanding the aspectual distribution in infinitival structures across languages.
\end{abstract}

Keywords. dative; infinitival constructions; null modal licensing; aspectual requirements; non-veridical operators

1. Introduction. Impersonal dative modal constructions (DMCs) are typical for many languages, including Russian (Fleisher 2006, Jung 2009, Moore \& Perlmutter 2000 among others), Polish (Greenberg \& Franks 1991), Hindi (Bhatt 1998), and others. In all cases, the dative subject appears with an infinitive (e.g., Russian, Polish) or a gerund (e.g., Hindi, Sindhi). A type of DMCs, to be discussed here, is a Russian construction that expresses a modality of obligation/necessity without an overt modal (1).

$\begin{array}{llllll}\text { Boris-u sdava-t' } & \text { ekzamen, (a } & \text { on } & \text { ne } & \text { gotov). } \\ \text { Boris-DAT } & \text { pass-INF } \\ \text { 'Boris has to take an exam, but he is not ready.' }\end{array}$

The phenomenon of null modals has been previously discussed in the literature. As von Fintel \& Gillies (2008) point out, modality may be expressed by various means including, but not limited to modal auxiliaries (may, must, should, etc.), semimodal verbs (has to), adverbs (possibly), adjectives (necessary), and conditionals. Some sentences, however, may receive the modal interpretation without overt modal elements.

First, I propose that the structure in (1) also involves a null/covert modal of necessity (e.g., NEED). Following Bhatt (1997), I show that neither the verb BE nor infinitives are responsible for the modal interpretation of (1). Assuming that DMCs are constructions with complex predicates (Fleisher 2006, Jung 2009), I propose that in (1), NEED selects a TP-less complement. The covert modal takes an AspP as its complement and assigns the dative case (DAT) to the base-generated embedded DP.

I then turn my discussion to the aspectual distribution in DMCs. I suggest that the null modal element is semantically deficient, and it requires special licensors. In particular, similar to

\footnotetext{
* I am very grateful to my advisors John F. Bailyn and Daniel Finer for thorough discussions and comments on various stages of this research. Special thanks to Susi Wurmbrand for helpful comments and very useful references. For helpful feedback, I am also grateful to three anonymous reviewers and the audience at the LSA 2020 annual meeting. Author: Anna Melnikova, Stony Brook University (anna.melnikova@stonybrook.edu).
} 
the covert future-oriented modal WOLL (Wurmbrand 2014, Todorović 2015, Todorović and Wurmbrand 2016), NEED has to be c-commanded by either tense or an element with the nonveridical feature $[+\mathrm{NV}]$.

2. The source of modality. In some languages, the lack of an overt modal does not prevent a sentence from receiving a modal interpretation.

(2) Indo-Aryan (Bhatt 1997:10)

Ram-ko seb khaa-naa (chahiye) thaa.

Ram-DAT fruit eat-GER (should) BE.PST

'Ram should have eaten the apple.'

Parallel to (2), the presence of the overt modal element is optional in DMCs (3).

$\begin{array}{lllll}\text { Boris-u } & \text { (nužno) } & \text { rabota-t' } & \text { do } & \text { ponedel'nika. } \\ \text { Boris-DAT } & \text { (need) } & \text { work-INF } & \text { ill } & \text { Monday } \\ \text { 'Boris has to work till Monday, } & & \end{array}$

In what follows, I show that neither the verb BE nor an infinitive contribute to modality in DMCs.

Fleisher (2006) and Jung (2009) claim that in infinitival modal constructions, the main verb byt' 'BE' is the source for 'covert' modality (4)1.
Gde
nam $\varnothing /$ bylo
igra-t'?
where us-DAT BE.PRES/PST
'Where do/did we have to play?'
play-INF

However, there are cases when BE appears in non-modal infinitival constructions as well (Bhatt 1998) (5).

$\begin{array}{lllll}\text { Veselo } & \varnothing / \text { bylo } & \text { igra-t' } & \mathrm{v} & \text { parke. } \\ \text { fun } & \text { BE.PRES/PST } & \text { play-INF } & \text { in } & \text { park }\end{array}$

'It is/was fun to play in the park.'

$=$ The event of playing in the park is/was fun.

Furthermore, example (6) shows that infinitives do not carry any modality either. The modal interpretation is more likely to be triggered by the matrix predicate xočet 'want' rather than by the embedded infinitive (Bhatt 1997).

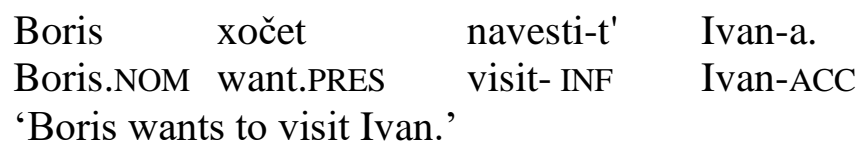

As Bhatt (2000) points out, deontic modality of necessity can emerge when an infinitival clause appears with [+wh] complementizes (7).

(7) English (Bhatt 2000: 120)

John knows [when to be at home].

$=$ John knows that being at home at time $\mathrm{t}$ satisfies the Goals/the Law.

Moreover, there are cases when [+wh] complementizes receive a modal interpretation lacking both an overt modal and an overt infinitival verb (8).

\footnotetext{
${ }^{1}$ In Russian, the verb BE is null in the present tense.
} 
Slovenian (Marušič \& Žaucer 2005: 9)

Tinčk-u so pokaza-l-i [kako do štacjona].

Tinček-DAT AUX.PST show-PST-PL [how to train-station]

'They showed Tinček how to go to train station.'

It seems plausible to assume that in all infinitival constructions, the modality stems from an interaction of a [+wh] and the infinitival [+inf] features of the clause. However, in Russian DMCs, modality in not necessarily associated with the [+wh] feature (1).

Since neither BE nor the infinitive seem to contribute the modal interpretation in DMCs without an overt modal element, and since such constructions do not have to involve the [+wh] feature, I suggest the alternative analysis: modality is expressed by a null modal element NEED. Generally, as Bhatt (1998) points out, across languages, it is not uncommon to express universal quantificational force by covert semantic operators (e.g., adverbs). I propose that covert NEED takes a complement that is smaller than a TP (e.g., AspP) (9).

$$
\text { NEED }\left[\operatorname{AspP}\left[\begin{array}{ll}
\mathrm{vP} & \ldots
\end{array}\right]\right]
$$

The main indicator for the AspP size of a complement clause is an unavailability of non-agreeing temporal adverb(ial)s2.

\begin{tabular}{|c|c|c|c|c|c|c|}
\hline $\begin{array}{l}* \text { Segodnja } \\
\text { today }\end{array}$ & $\begin{array}{l}\text { Boris-u } \\
\text { Boris-DAT }\end{array}$ & $\begin{array}{l}\varnothing \\
\text { NEED }\end{array}$ & $\begin{array}{l}\text { sdava-t' } \\
\text { take-INF }\end{array}$ & $\begin{array}{l}\text { ekzamen } \\
\text { exam }\end{array}$ & $\begin{array}{l}\text { čerez } \\
\text { in }\end{array}$ & $\begin{array}{l}\text { dva } \\
\text { two }\end{array}$ \\
\hline
\end{tabular}

DMCs with covert NEED structurally resemble English non-finite future-oriented contructions that comprise an abstract future modal wOLL and a verb in the infinitival form (Wurmbrand 2014, Todorović \& Wurmbrand 2016) (11).

(11) English (Wurmbrand 2014: 413)

Leo decided a week ago to go to the party.

According to Wurmbrand (2014), the infinitival clause to go to the party in (11) would have the following representation (12):

\section{(12) WOLL [ vP PRO infinitive]}

Similar to Wurmbrand's infinitival clauses, DMCs are future-oriented. The difference is that the latter can appear in isolation (e.g., they don't have to be selected by the higher overt predicate as decide in (11), for example). I would like to propose that despite some structural differences between future infinitival clauses and DMCs, they are similar in the sense that both constructions involve an abstract future modal that is located below T. Moreover, in what follows, we will see that similar to WOLL, covert NEED has to be licensed either by tense or by irrealis/non-veridical elements via AGREE.

3. Aspect Requirements. The puzzle to be explored in this section is why DMCs with covert modal elements are restricted in their aspectual choice. In particular, imperfective infinitives are possible in declarative environments (13).

\footnotetext{
${ }^{2}$ Availability of non-agreeing adverb(ial)s in constructions with intensional transitive verbs indicates that a matrix event and an embedded event refer to two distinct time intervals (Larson et al. 2018, Marušič \& Žaucer 2005).

(i) [Yesterday, Peter wanted [PRO to buy a book tomorrow]].

In (i), 'yesterday' modifies the overt predicate want in the matrix clause, and 'tomorrow' modifies the lower infinitive 'to buy'.
} 

Boris-u $\varnothing \quad$ poluč-at'
zarplat-u.
Boris-DAT NEED get-IPFV.INF
payment-ACC
'Boris needs to be getting paid.'

Crucially, perfective infinitives are not compatible with declaratives (14), but are allowed in irrealis/non-veridical environments, such as negation (Neg), questions (Q), subjunctives (Subj), and imperatives (Imp)) (15) - (18).
*Boris-u
$\varnothing \quad$ poluč-it'
zarplat-u.
Boris-DAT
NEED get-PFV.INF
payment-ACC

'Boris needs to get paid.'

$\begin{array}{lllll}\text { Boris-u ne } & \varnothing & \text { poluč-it' } & \text { zarplat-uz. } \\ \text { Boris-DAT } & \text { NEG } & \text { MOD } \\ \text { 'Boris is not able to get paid.PFV.INF } & \text { payment-ACC }\end{array}$

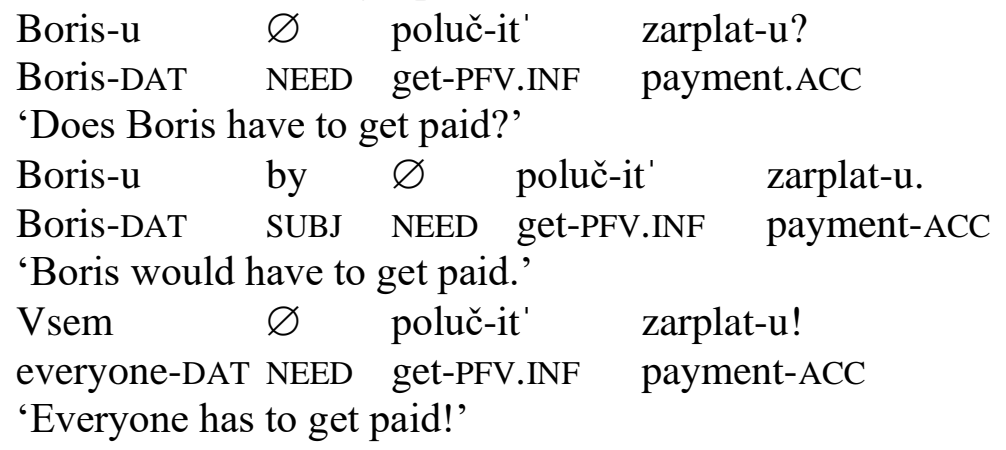

In the spirit of Todorović and Wurmbrand (2016), I suggest that the grammaticality of DMC is determined by the presence/absence of a licensor for the covert NEED. In what follows, I show that the (un)availability of the licensor is derived from semantic properties of imperfective/perfective aspects.

3.1. ASPECT AND THE TIME INTERVALS. Sematically, imperfective/perfective aspects can be explained in terms of the interaction between time intervals: Event Time $(E)$, Reference Time $(R)$, and Speech Time (Reichenbach 1947). Speech Time (S) determines when the sentence is spoken (the actual time of the utterance). Event Time determines when the described event is true or is claimed to be true with respect to $S$. Reference Time $(R)$ restricts the time interval for a given statement (Todorović 2015). According to Kratzer (1998), aspects have the following semantic representations (19) and (20):
$[[$ IMPERFECTIVE $]]=\lambda \mathrm{P} . \lambda \mathrm{t} \cdot \exists \mathrm{e}[\mathrm{t} \subset \tau(\mathrm{e}) \& \mathrm{P}(\mathrm{e})]$
Reference time must be included in Event Time $(\mathrm{R} \subset \mathrm{E})$.
$[[$ PERFECTIVE $]]=\lambda \mathrm{P} \cdot \lambda \mathrm{t} . \exists \mathrm{e}[\tau(\mathrm{e}) \subseteq \mathrm{t} \& \mathrm{P}(\mathrm{e})]$
Event time must be included in Reference Time ( $\subseteq \subseteq \mathrm{R})$.

Bhatt \& Pancheva (2005), Wurmbrand (2014), Todorović (2015), and many others, suggest that cross-linguistically, the ungrammaticality of perfective stems from its incompatibility with the

\footnotetext{
${ }^{3}$ In perfective contexts, a different type of modality (be able to) arises with negation. In this research, I consider both be able to and need as covert future-oriented modals. Crucially, both types are semantically deficient and require additional irrealis/non-veridical licensors.
} 
higher temporal domain. For instance, in English (20) and BCS (21), perfective cannot occur in the present tense structures.

(20) English (Todorović and Wurmbrand 2016: 2) 4 Mary *sleeps/ $\sqrt{ }$ is sleeping right now.

(21) BCS (Todorović and Wurmbrand 2016: 2)

Milan prevodi /*prevede pesmu.

Milan translates-3SG.PRES.IPFV/*...PFV poem

'Milan is translating a poem (right now).' (imperfective)

*'Milan has translated a poem (just now).' (perfective)

In (20) and (21), $R$ is introduced by the present tense, which is near-identical to Speech Time (22) (Todorović 2015: 88). Thus, $R$ is too short to include $E$, which violates the requirement on perfective.

$[[$ PRESENT 1$]]=\lambda \mathrm{p} . \lambda \mathrm{t} . \lambda \mathrm{w} . \exists \mathrm{t}_{1}\left[\mathrm{t}_{1}=\mathrm{t} \& \mathrm{P}\left(\mathrm{t}_{1}\right)\right]$

The reference time interval $\left(\mathrm{t}_{1}\right)$ must be equal to the time of speech $(\mathrm{t})$.

As for the past and future tenses, they define $R$ as an unspecified and potentially long time interval (unless contextually modified). Therefore, they are long enough to include $E$, satisfying the perfective requirement. Thus, in the past tense, $R$ is not is not temporally restricted.

Borik (2002) notices that the requirements on imperfective and perfective in (19) and (20) are not able to explain the aspectual opposition in Russian. Consider the following examples:
$\mathrm{Na}$ prošloj nedele Boris vy-my-1 okno.
on last week Boris PFV-clean-PST window

'Last week, Boris cleaned the window.'
$\mathrm{Na}$ prošloj nedele Boris my-1
on last week Boris clean-PST.IPFV window (and by Friday PFV-finish-PST)
'Last week, Boris was cleaning the window (and he finished by Friday).'

In (23), $R$ is introduced by the past tense and is contextually specified by the adverbial phrase $n a$ prošloj nedele 'last week'. Clearly, the event of cleaning the window is included in $R(\mathrm{E} \subseteq \mathrm{R})$. In (24), the time of the event seems also to be included in $R$, since the time of the cleaning event $(E)$ did not take place for the whole week $(R)$, but was finished by Friday. Despite the aspectual differences, in both examples, there is some time interval $E$ which is included in the time interval in the past, specified by na prošloj nedele. The definition in (25) accounts for these similarities (Partee 1984, Reinhart 1986, Borik 2002).

(25) For both aspects: Event time must be included in Reference Time $(\mathrm{E} \subseteq \mathrm{R}) 5$

The definition in (25) cannot explain the differences between imperfective and perfective aspects in Russian. To account for this potential problem, Borik (2002) suggests including the $S$ - $R$ relation in defining aspect. In perfective, the relation is based on the notion of precedence. In the past, Reference Time precedes Speech Time $(R<S)$. In the future, it follows Speech Time $(R>$ $S)$. In the imperfective environment, there is an overlap between $S$ and $R(R \cap \mathrm{S})$. The evidence

\footnotetext{
${ }^{4}$ Todorović and Wurmbrand (2016) treat the progressive/non-progressive opposition in English as the imperfective/perfective contrast.

${ }^{5}$ The progressive operator reverses the E-R relation (e.g., the English progressive): $\mathrm{E} \subseteq \mathrm{R} \rightarrow \mathrm{R} \subseteq \mathrm{E}$ (for details, see Reinhart 1986).
} 
that only imperfective involves an overlap between $R$ and $S$ comes from the fact that in Russian, only imperfective non-past forms are associated with the semantic present.

In Russian, the past tense is expressed by the past tense morpheme $-l$-. Present and future, however, do not show morphological distinctions and can be referred to as non-past (Comrie 1976) (Table 1).

\begin{tabular}{|lll|}
\hline Tense & Imperfective & Perfective \\
\hline Past & govor-il & po-govor-il \\
& talk- M.SG & PFV-talk- M.SG \\
Non-past & govor-it & \\
& talk-3.SG & \\
& bud-et govori-t' & po- govor-it \\
& BE-3.SG talk-INF & PFV-talk-3.SG \\
\hline
\end{tabular}

Table 1: Tense and Aspect in Russian

Imperfective non-past can be expressed by either the periphrastic form bude-t govorit' 'BE + infinitive' or the simple form. Periphrastic structures can only be interpreted as future and never as present (26).

$\begin{array}{lllll}\text { Sejčas Boris budet pet' } & \text { Karnegi } & \text { Hole. } \\ \text { now Boris BE.PRES sing-INF.IPFV in Carnegie } & \text { Hall } \\ \text { 'Now, Boris will be singing in Carnegie Hall.' } & & \\ \text { *'Now Boris is singing in Carnegie Hall.' (periphrastic) } & \end{array}$

The simple imperfective form can be interpreted either as future or as present (27).

$\begin{array}{lllllll}\text { Zavtra } & \text { /sejčas } & \text { Boris } & \text { poet } & \mathrm{v} & \text { Karnegi } & \text { Hole. } \\ \text { tomorrow } & \text { /now } & \text { Boris } & \text { sing.PRES.IPFV } & \text { in } & \text { Carnegie } & \text { Hall }\end{array}$

'Tomorrow Boris will be singing in Carnegie Hall.'

'Now Boris is singing in Carnegie Hall.' (simple)

As for perfective non-past, it does not allow periphrastic forms (28), and its simple form is restricted to future interpretation only (29).

$\begin{array}{lllll}\text { *Zavtra Boris bud-et spet' } & \mathrm{v} \text { Karnegi } & \text { Hole. } \\ \text { tomorrow Boris BE-3sG.PRES sing.PFV.INF in Carnegie } & \text { Hall } \\ \text { 'Tomorrow, Boris will sing in Carnegie Hall.' (periphrastic) } & \\ \text { Zavtra/ *sejčas Boris s-poet } & \mathrm{V} \text { Karnegi } & \text { Hole. } \\ \text { tomorrow /*now Boris PFV-sing.PRES in Carnegie } & \text { Hall } \\ \text { 'Tomorrow Boris will perform in Carnegie Hall.' } & & \\ \text { *'Now Boris is singing in Carnegie Hall.' } & & \end{array}$

To sum up, unlike imperfective, perfective non-past forms are not associated with semantic present in Russian (Table 2).

\begin{tabular}{|l|c|c|}
\hline \multicolumn{1}{|c|}{ TENSE/INTERPRETATION } & IMPERFECTIVE & PERFECTIVE \\
\hline present & + & - \\
\hline future & + & + \\
\hline
\end{tabular}

Table 2. Distribution of Non-past Tense in Russian (Borik 2002:143) 
Thus, in both imperfective and perfective aspects in Russian, Event Time $(E)$ is included in Reference Time $(R)$ by default: $\mathrm{E} \subseteq \mathrm{R}$. What distinguishes the two aspects in non-past forms is the relation between $S$ and $R$. Only imperfective involves the overlap of the two time intervals: $R$ $\cap \mathrm{S}$.

In the spirit of Abusch $(1985,1988)$, Wurmbrand (2014), and many others, I suggest that similar to English and BCS, the future tense in Russian comprises two parts: the semantic present [PRES] and an abstract future modal (e.g., WOLL)6. However, in Russian, the [PRES] component appears exclusively on imperfective non-past forms, which is motivated by the incompatibility of present interpretation with perfective forms. In what follows, I show that the aspectual distribution in DMCs is attributed to the fact that [PRES] is only projected in imperfective structures.

Section 3.2 is a brief discussion of licensing conditions on the covert future modal WOLL in finite and infinitival contexts. Crucially, the distribution of covert NEED in Russian DMCs strikingly resembles the distribution of covert WOLL.

3.2. LICENSING OF WOLL IN ENGLISH AND BCS. As mentioned in 3.1, finite future constructions have the abstract covert future modal WOLL and the semantic tense (e.g., [PRES]). Wurmbrand (2014) proposes that in finite future contexts, WOLL can be licensed by the semantic present or past tense (30) and (31).

(30) Leo will/would go to the party.

(31) T [PRES/PST] [ ModP WOLL [F:

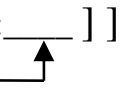

Infinitival future constructions, however, lack the tense component and, thus, WOLL requires additional licensors (e.g., a future-oriented verb decide) (32).

English (Todorović and Wurmbrand 2016: 5)

Leo decided to sleep in the garage tomorrow.

Additionally, when the tense component is absent, the covert modal WOLL 'must be identified structurally by an irrealis element' (Todorović and Wurmbrand 2016:7)7. The following BCS

${ }^{6}$ The evidence for the complex structure of future tense in English comes from the following examples:

(i) a. Tomorrow, I will tell you everything I do today.

b. This year, I will get rid of all my books that I forgot to read.

In (i(a)), the embedded present event I do today receives the future interpretation from matrix will. In (i(b)), the past event $I$ forgot to read refers to the time interval that precedes not the speaking time, but rather matrix future. Thus, there must be a temporal operator (e.g., WOLL) that shifts the embedded tense (Abusch 1988, Wurmbrand 2014, Todorović 2015). The finite future constructions in (i) have the following representation:

(ii) [тр PRES [wollP WOLL [vP ...]]]

The present and the future in Russian do not show morphological distinctions (e.g., govori -t 'talk'/ bude-t govorit' 'will be talking / po- govori-t 'will talk'), and they are referred to as non-past. Unlike in English, Russian wOLL is covert. In other words, it is not morphological, but rather semantic future marker. Representation of English and Russian future tense in finite clauses is given below.
a. English:
Pres, WOLL $\rightarrow$ will
Past, WOLL $\rightarrow$ would
b. Russian:
Pres, WOLL(null) $\rightarrow \varnothing$

7 Todorović and Wurmbrand (2016: 8) claim that 'the visible morphological tense is not a semantic tense' in the given examples. 
examples are only grammatical in non-veridical environments, such as imperatives (33a) and questions (33b), but not in declaratives (34).

(33) BCS irrealis constructions (Todorović and Wurmbrand 2016: 7)
a. Da ti se sve želje ostvare!
DA you.DAT SE all wishes come.true.PRES
'May all your wishes come true!'
b. Da li da Vesna pročita ovu knjigu?
Q DA Vesna read.3.PRES this book
'Should Vesna read this book?'

(34) BCS declarative construction (Todorović and Wurmbrand 2016: 7)

*Da Vesna pročita ovu knjigu.

DA Vesna read.PRES. this book.

'Vesna should read this book.'

The licensing mechanism of the covert modal WOLL in non-finite constructions is in (35).

(35) BCS (Todorović and Wurmbrand 2016: 8)
a. C [IRR] [TP/ModP WOLL [F:

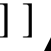
b. ${ }^{*} \mathrm{C}$ [DECLARATIVE] [TP/ModP WOLL [F: ]]

3.3. LICENSING OF THE COVERT FUTURE MODAL IN RUSSIAN DMCS. To formally account for the aspect asymmetries in Russian DMCs, I propose that the observed restrictions in (13) - (18) are parallel to restrictions in future - oriented constructions in English and BCS (Wurmbrand 2014, Todorović 2015). In particular, similar to English and BCS future constructions, DMCs involve a covert future modal (e.g., NEED), which is semantically deficient and requires a licensor.

The difference between imperfective and perfective DMCs is in the (un)availability of the tense component. Since [PRES] is projected only in imperfective environments, NEED can be selected (licensed) by the semantic present tense only in imperfective DMCs in the same manner the future modal WOLL is licensed in finite future contexts (36).
Boris-u $\varnothing \quad$ poluč-at'
zarplatu, (a ego net).
Boris-DAT NEED get-IPFV.INF payment (but he.GEN NEG)
'Boris needs to be getting paid, (but he is not here).

The syntactic representation of (36) is given in (37).

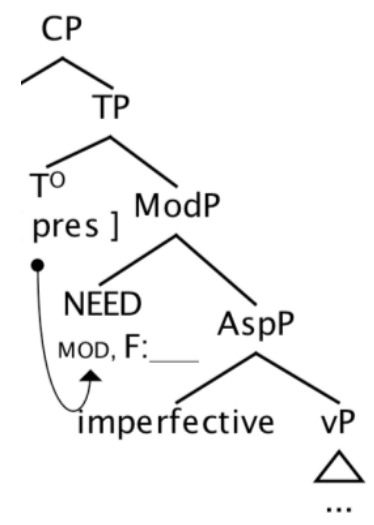


The configuration PRES, NEED in (37) also accounts for requirements on non-past imperfective (Borik 2002): a. Event Time is included in Reference Time by default $(\mathrm{E} \subseteq \mathrm{R})$; b) there is an overlap between Reference Time and Speech Time $(R \cap \mathrm{S})$.

In the spirit of Todorović and Wurmbrand (2016), I propose that in imperfective DMCs, $R$ is introduced by tense [PRES], which is 'near-instantaneous' with respect to Speech Time by the definition for the present tense, repeated in (37).

$$
\begin{aligned}
& {[[\text { PRESENT } 1]]=\lambda \mathrm{p} . \lambda \mathrm{t} . \lambda \mathrm{w} . \exists \mathrm{t}_{1}\left[\mathrm{t}_{1}=\mathrm{t} \& \mathrm{P}\left(\mathrm{t}_{1}\right)\right]} \\
& \text { The reference time interval }\left(\mathrm{t}_{1}\right) \text { must be equal to the time of speech }(\mathrm{t}) \text {. }
\end{aligned}
$$

The fact that $R$ introduced by the present tense is too short to include $E$ (e.g., polučat 'zarplatu 'get paid'), is not a problem for imperfective DMCs, since like any other modals, covert future NEED extends $R$ (Todorović 2015), satisfying the $\mathrm{E} \subseteq \mathrm{R}$ requirement on Russian aspect.

Additionally, by the definition in (37), the [PRES] component introduces $R$ that is the same as $S$, resulting in the overlap between the two time intervals, which satisfies the second condition for imperfective: $(R \cap \mathrm{S})$.

As for the non-past (future) perfective, we saw that it cannot be associated with the semantic present tense. The lack of the tense component in perfective DMCs result in ungrammatical structures since the covert modal NEED requires a licensor (38).

\begin{tabular}{|c|c|c|c|c|}
\hline $\begin{array}{l}\text { *Boris-u } \\
\text { Boris-DAT }\end{array}$ & $\begin{array}{l}\varnothing \\
\text { NEED }\end{array}$ & $\begin{array}{l}\text { poluč-it' } \\
\text { get-PFV.INF }\end{array}$ & $\begin{array}{ll}\text { zarplatu, (a } \\
\text { payment (but }\end{array}$ & $\begin{array}{l}\text { ego net). } \\
\text { he.GEN NEG) }\end{array}$ \\
\hline
\end{tabular}

To account for the fact that (38) becomes grammatical in such environments as negation, questions, subjunctives, imperatives, and etc, I will follow Todorović and Wurmbrand's approach (2016), and suggest that the covert future modal can be licensed not only by tense, but also by other c-commanding operators via AGREE. In particular, covert NEED can be selected by irrealis operators that check the non-veridical (irrealis) feature [+NV]8 (39).

\footnotetext{
Boris-u $\varnothing$ poluč-it' zarplatu?

Boris-DAT NEED get-PFV.INF payment?

'Does Boris have to get paid?'
}

\footnotetext{
${ }^{8}$ The notion of veridicality is based on truth (Giannakidou 2008). For instance, the verb to see is veridical, because I saw a unicorn implies that the unicorn exists. On the other hand, to look for is nonveridical, since the sentence $I$ am looking for a unicorn does not necessary suggest the existence of the unicorn. Thus, veridicality of the propositional operator $F$ depends on whether or not $F p$ entails $p$.

i. Non-veridicality (Giannakidou 2008: 12)

a. A propositional operator $F$ is veridical iff $F p$ entails or presupposes that $p$ is true in some individual's epistemic model $\mathrm{ME}(\mathrm{x})$; otherwise, $F$ is nonveridical.

b. A nonveridical operator $F$ is antiveridical iff $F p$ entails that not $p$ in some individual's epistemic model: $F p \rightarrow \neg p$ in some $\mathrm{ME}(\mathrm{x})$. (ME(x) denotes a set of epistemic worlds of $x$-individual)

Modals, subjunctive, imperatives, and questions do not assert the truth, therefore, they are nonveridical.

- $\quad$ ii. a. You must find the key. $\neq$ You found the key.

b. John would drink beer. $\neq$ John drank beer.

c. Close the window $! \neq$ (Someone) closed the window.

d. Did John go to the park? $\neq$ John went to the park.

Negation is an antiveridical operator, which is in the subset of nonveridical operators. For instance, in John did not see a snake, $F p$ does not entail the truth of $p$, because it entails that $p$ is false.
} 
The syntactic representation of (39) is given in (40).

(40)

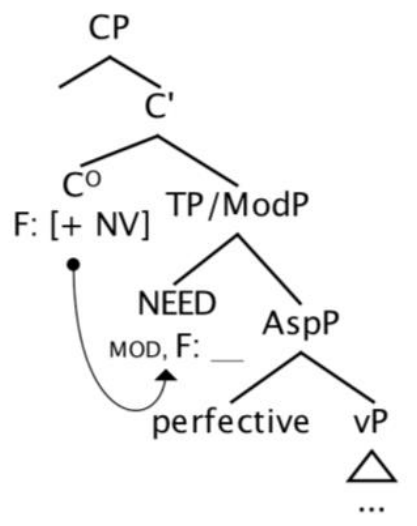

Similar to imperfective DMCs, in perfective structures, $R$ is specified by the covert modal as indefinitely long, and, thus, it is able to include the time interval of the embedded event $E$ ( $\mathrm{E} \subseteq$ $\mathrm{R})$. In declarative environments, licensing of the covert modal is not possible due to the absence of the [+NV] feature. Therefore, the overt modal must be present (41).
Boris-u nužno
poluč-it'
zarplatu.
Boris-DAT need[-AGR]
payment

'Boris needs to get paid.'

To sum up, similar to future constructions, the aspectual asymmetries between imperfective and perfective DMCs can be attributed to the availability of the present tense. Perfective DMCs lack the [PRES] tense component, and, thus, the null modal NEED requires additional licensors.

4. Conclusion. In this paper, I proposed that Russian dative infinitival constructions involve the covert modal of necessity NEED. The arguments for the existence of a silent modal element are based on semantic properties of infinitival constructions. In particular, we saw that neither BE nor the infinitive itself can be the source of modality. Moreover, contrary to Bhatt (2000), I suggest that the [+wh] feature is not relevant to modality in DMCs either since such constructions can receive the modal interpretation without this feature.

I compared Russian DMCs to Wurmbrand's (2014) future constructions and accounted for the licensing conditions on the covert future modal NEED in terms of the imperfective/perfective distribution and aspectual requirements. The licensing conditions on covert future modals lay the foundation to understanding the aspectual distribution in infinitival structures across languages. For instance, in BCS, both imperfective and perfective future-oriented modal constructions are ungrammatical without non-veridical licensors. Their ungrammaticality can be possibly attributed to the absence of the temporal domain above the covert future WOLL, if we assume that in both contexts, the visible morphological present tense is treated as 'semantically vacuous' (Todorović and Wurmbrand 2016).

\section{References}

Abusch, Dorit. 1985. On verbs and time. Amherst, MA: University of Massachusetts dissertation.

Abusch, Dorit. 1988. Sequence, tense, intensionality, and scope. In Hagit Borer (ed.), Proceedings of the 7th West Coast Conference on Formal Linguistics. 1-14. Stanford, CA: CSLI Publications. 
Adger, David. 2003. Core syntax: A minimalist approach. Oxford: Oxford University Press. Bailyn, John F. 2012. The syntax of Russian. Cambridge: Cambridge University Press.

Bhatt, Rajesh. 1998. Obligation and possession. In Heidi Harley (ed.), Papers from the UPenn/MIT Roundtable on Argument Structure and Aspect. Cambridge, MA: MITWPL.

Bhatt, Rajesh. 2000. Covert modality in non-finite contexts. Berlin: Walter de Gruyter.

Bhatt, Rajesh \& Roumyana Pancheva. 2005. The syntax and semantics of aspect. LSA Summer Institute, handout.

Cover, Rebecca T. 2010. Aspect, modality, and tense in Badiaranke. Berkeley, CA: University of California dissertation.

Davies, William D. \& Stainley Dubinsky. 2008. The grammar of raising and control: A course in syntactic argumentation. Hoboken, NJ: John Wiley \& Sons.

Fleisher, Nicholas. 2006. Russian dative subjects, case, and control. Berkeley, CA: University of California manuscript.

Fortuin, Egbert. 2007. Modality and aspect: Interaction of constructional meaning and aspectual meaning in the dative-infinitive construction in Russian. Russian Linguistics 31(3). 201230. https://www.jstor.org/stable/pdf/40221286.

Greenberg, Gerald R. \& Steven Franks. 1991. A parametric approach to dative subjects and the second dative in Slavic. Slavic and East European Journal 35 (1). 71-97. https://www.jstor.org/stable/pdf/309034.

Giannakidou, Anastasia. 2002. Licensing and sensitivity in polarity items: from downward entailment to nonveridicality. Chicago Linguistic Society (CLS) 38. 29-53.

Giannakidou, Anastasia. 2008. Negative and positive polarity items: Variation, licensing, and compositionality. In Maienborn, Claudia, Klaus von Heusinger \& Paul Portner (eds.), Semantics: An international handbook of natural language meaning. Berlin: De Gruyter Mouton.

Jung, Hakyung. 2009. Null prepositional complementizers and the dative of obligation in Russian. Proceedings of Formal Approaches to Slavic Linguistics 17. 64-81.

Ilić, Tatjana. 2013. Modality and causation in Serbian dative anticausatives: A crosslinguistic perspective. Manoa, HI: University of Hawai'i dissertation. http://www.ling.hawaii.edu/graduate/Dissertations/TatjanallicFinal.pdf

Kratzer, Angelika. 1981. The notional category of modality. In Hans J. Eikmeyer \& Hannes Rieser (eds.), Words, worlds, and contexts: New approaches in word semantics. 38-74. Berlin: De Gruyter Mouton.

Kratzer, Angelika. 1991. Modality. In Arnim von Stechow \& Dieter Wunderlich (eds.), Semantics: An international handbook of contemporary research. 639-650. Berlin: Walter de Gruyter.

Larson, Richard, Marcel den Dikken \& Peter Ludlow. 2018. Intensional transitive verbs and abstract clausal complementation. In Alex Grzankowski \& Michelle Montague (eds.), Nonpropositional intensionality. Oxford: Oxford University Press.

Lobeck, Anne C. 1995. Ellipsis: Functional heads, licensing, and identification. Oxford: Oxford University Press.

Marušič, Franc \& Rok Žaucer. 2005. On phonologically null verbs: GO and beyond. In Sylvia Blaho, Luis Vicente \& Erik Schoorlemmer (eds.), Proceedings of ConSOLE XIII. 231-248.

Moore, John \& David M. Perlmutter 1999. Case, agreement, and temporal particles in Russian infinitival clauses. Journal of Slavic Linguistics 7(2). 219-246.

https://www.jstor.org/stable/24599646.

Moore, John \& David M. Perlmutter. 2000. What does it take to be a dative subject. Natural 
Language \& Linguistic Theory 18(2). 373-416. https://doi.org/10.1023/A:1006451714195.

Perlmutter, David M. 1970. The two verbs “begin.” In Roderick Jacobs and Peter Rosenbaum, (eds.) Readings in transformational grammar. 107-19. Waltham, MA: Ginn.

Reichenbach, Hans, 1947. Elements of symbolic logic, New York: Macmillan.

Reinhart, Tanya. 1984. Principles of Gestalt perception in the temporal organization of narrative texts. Linguistics 22(6). 779-809.

Richardson, Kylie. 2007. Case and aspect in Slavic. Oxford: Oxford University Press.

Rivero, María L. 2009. Intensionality, high applicatives, and aspect: involuntary state constructions in Bulgarian and Slovenian. Natural Language \& Linguistic Theory 27(1). 151-196. https://doi.org/10.1007/s11049-008-9059-8.

Todorović, Neda. 2015. Tense and aspect (in)compatibility in Serbian matrix and subordinate clauses. Lingua 167. 82-111. https://doi.org/10.1016/j.lingua.2015.04.007.

Todorović, Neda \& Susi Wurmbrand. 2016. Finiteness across domains. Storrs, CT: University of Connecticut manuscript.

Tonhauser, Judith. 2006. The temporal semantics of noun phrases: Evidence from Guaraní. Stanford, CA: Stanford University dissertation.

Von Fintel, Kai \& Anthony Gillies. 2008. An opinionated guide to epistemic modality. In Tamar Szabo Gendler \& John Hawthorne (eds.), Oxford studies in epistemology (Volume 2). 2362.

Wurmbrand, Susi. 2014. Tense and aspect in English infinitives. Linguistic Inquiry 45(3). 403447. https://doi.org/10.1162/LING a 00161.

Zhang, Jinghua. 2016. Cross-linguistic variations of pro licensing conditions. Journal of Language Teaching and Research 7(3). 499-504. 